Dorival Pinheiro Garcia', José Cláudio Caraschi², Gustavo Ventorim², Fabio Henrique Antunes Vieira'

\title{
TRENDS AND CHALLENGES OF BRAZILIAN PELLETS INDUSTRY ORIGINATED FROM AGROFORESTRY
}

Keywords:

Biomass

Renewable energy

Wood pellets

Agropellets

Histórico:

Recebido 24/12/2015

Aceito 1 I/07/2016

Palavras chave:

Biomassa

Energia renovável

Pellets de madeira agropellets

Correspondência: pelletsdemadeira@gmail.com
ABSTRACT: Wood pellets are biofuels produced from agroforestry waste such as sugarcane bagasse, wood sawdust and shavings. They are compressed biofuels that have low moisture, allowing high combustion efficiency, especially because they are natural products of easily handling with high energy density. To explore pellets opportunities in Brazil (production and marketing), it is necessary to provide information about the chemical and energy characteristics, technologies, prices and prospects of this market. Thus, this article aims to organize and make this information available, enabling general knowledge on the subject and subsidize more investment in the biofuels sector; mostly by adding value to agroforestry waste, available in large volumes in this country. The results showed a young industry, with sixteen plants and production of 49.39 ktonnes of pellets in 2014 , but using only $25.5 \%$ of its annual production capacity.

\section{TENDÊNCIAS E DESAFIOS DA INDÚSTRIA BRASILEIRA DE PELLETS DE ORIGEM AGROFLORESTAL}

RESUMO: Os pellets são biocombustíveis que podem ser produzidos a partir de resíduos agroflorestais como o bagaço de cana, serragem e maravalha de madeira. São biocombustíveis compactados que tem baixa umidade, permitindo elevada eficiência na combustão, destacando-se por ser um produto natural de fácil manuseio e alta densidade energética. Para explorar as oportunidades de negócios com pellets no Brasil (produção e comercialização) necessita-se oferecer informações a respeito das tecnologias utilizadas, preços e as perspectivas futuras deste mercado. Desta forma, este artigo busca organizar e disponibilizar essas informações, possibilitando o conhecimento do mercado de pellets no Brasil e subsidiar mais investimentos no setor de biocombustíveis, sobretudo agregando valor aos resíduos agroflorestais disponíveis em grande volume nesse país. Os resultados mostraram uma indústria jovem, com dezesseis plantas industriais que produziram 49.390 t de pellets em 2014 , mas que utilizam apenas $25,5 \%$ de sua capacidade de produção atual. 


\section{INTRODUCTION}

Wood pellets are used more and more frequently as an energy source in equipment for household, commercial and industrial heating (ARRANZ et al., 2015). Wood is the main raw material of pellets, but not the only one. In Brazil, agro-forestry residues such as sugarcane bagasse and sawdust (Pinus and Eucalyptus) are used for the production of pellets. However, there are other options under study, such as the use of elephant grass (Pennisetum sp) and black wattle (Acacia mearnsii) as a feedstock. These types of biomass can be compressed by a pelletization process and present low moisture content, enabling efficiency during combustion. The regular and cylindrical geometry formed after pelletization enables automatic feed in various industrial systems, such as in residential heaters.

In this scenario, pellets stand out because they are easy to handle natural products. They require little storage space and have high energy density. Their main application is for generation of thermal energy but they can also be used as fuel for the generation of electricity in industry or power plants. Moreover, wood pellets are negotiated as granular toilet for small animals, which replaces cat litter, because of their adsorptive characteristics (BASU et al., 20I I; GARCIA et al., 20I3).

The use of pellets benefits the environment, being a low-carbon energy, i.e. almost all the $\mathrm{CO}_{2}$ emitted in their burning is recovered on plant growth (GARCIA et al., 20 I6; JOHNSTON; VAN KOOTEN, 20 I 5; WALTER; DOLZAN, 20I4). Brazil is the country that most uses biomass for energy production, 16\% of world use (WALTER; DOLZAN, 20I4). The South and Southeast regions in Brazil have the highest energy generation potential from agroforestry biomass due to the high concentration of forest plantations and sugarcane (FELFLI et al., 20I I).

Brazil stands out as an agricultural country and every year, about 330 Mtonnes of biomass waste are generated in the country, which is not used as energy by the lack of ideal characteristics such as low-density, low calorific value and high moisture content (FELFLI et al., 20I I; YAMAJl et al., 20I3). These negative qualities hinders its use because it results in high transport costs, difficulty in handling and storage, as well as low energy density. Brazil has the potential for pellet production, taking advantage of the large volume of available agroforestry waste (YAMAJl et al., 2013).

New industrial projects have emerged with the purpose of planting, besides Pinus and Eucalyptus, black wattle (Acacia mearnsi), giant bamboo (Dendrocalamus giganteus), elephant grass (Pennisetum sp) and sugarcane bagasse (Saccharum officinarum). However, not all agroforestry biomasses are suitable for the production of pellets mainly due to mineral elements responsible for the formation of residual ash. The Rice straw, for example, have up to $15 \%$ of ash content and values above $4 \%$ are considered unsuitable for combustion due to the high silica content, which can cause corrosion and excessive wear in the burners (DIAS et al., 20I2; RAMOS and PAULA et al., 20I I). After the assessment of agricultural waste, such as rice straw, sugarcane bagasse, coconut shell, among others, it was found they have potential to generate thermal energy. However, with non-residential use limitation of those with ash content higher than $0.7 \%$, as specified by European standard ISO I7225-6 (ISO, 20I4), for non-wood pellets.

The viability of using agroforestry waste in Brazil is subject to distance and logistics of collecting, impacting transport costs. As for the production of biofuel in the country, the data diverges between 20.0 ktonnes/y (LAMERS et al., 20I2), 47.0 ktonnes/y (IBÁ, 20I5) and 62.0 ktonnes/y (FORTI; HEMRARD, 20I4). After pellets became commodities traded worldwide (PROSKURINA et al., 2016), Brazil has been named as one of the main actors in this agroforestry biomass segment; increasing the necessity for more reliable and accurate data on pellets market. Thus, to explore the opportunities of this business (production and marketing) it is important to provide information regarding the availability of raw materials, domestic and foreign markets, chemical and energy characteristics and potential clients. Therefore, this article is intended to provide information on pellets market, increasing the general knowledge on pellets industry in Brazil, to encourage investments in this sector (particularly adding value to agroforestry waste), as well as to analyze the sector in the country, outlining the future challenges of this industry.

\section{METHODOLOGY}

The official figures on agroforestry pellets are few and inadequate in Brazilian market. So, a survey of general information from the nineteen producers (producing + ready to produce + disabled) and members of the Brazilian Association of Pellets Industry - ABIPEL was held from May to July 20I5. The exploratory research aimed at producing a qualitative and quantitative description of the pellets industry in Brazil. The questionnaire method was used because it is faster and more economical, especially considering that industries are widely dispersed geographically. Moreover, the questions posed in the 
questionnaire were open, simple and direct, and the respondents needed little technical knowledge to answer them. The research began by sending a questionnaire to companies (population) and those that did not respond, were contacted via telephone and e-mail. The objective was to diagnose the profile of producers, production capacity, technology used, prices, main raw material, year of startup, and the current state of the industry to create the Map of Pellets 20I4. The response rate was $89.5 \%$, a significant percentage due to the questionnaire method and the dispersion of industries among various regions of Brazil. Seventeen valid questionnaires were collected and only one company was not found. Another refused to answer. Still, the main information from these companies was obtained via telephone. The survey, with a tabulation of all questionnaires prepared by simple statistics, represents the treatment of the answers, allowing check of the results and generalization of about the surveyed population.

To create the map of pellets in Brazil in 2014, the producing industries were categorized into four types. Industries that are producing, indicating the companies that are manufacturing pellets normally. Industries that are ready to operate, representing companies that have the plant and equipment ready for production, but are not currently producing. Disabled industries, representing those that have disabled their equipment and are no longer producing pellets. Finally, those that are still under construction, representing future developments that have been announced, but are still under implementation. The pellet producers were identified by a number, their city and their state, to avoid positive or negative promotion of their trademarks.

\section{RESULTS AND DISCUSSION}

The results of the questionnaires analysis are shown in Table 2. Some parameters were found that characterize these industries, such as production capacity, technology and main raw materials used in the manufacture of agropellets.

It is possible to infer that the agroforestry biomass pellet industries in Brazil are relatively young; they have started in 2004, and have great potential for expansion. In Europe and North America, the emergence of this renewable fuel, occurred more than thirty-five years ago, in the late 70s, to solve the oil crisis (OBERNBERGER; THEK, 2004). Thus, the agropellet market in Brazil, compared to the major producing countries, has a time gap of about twenty-five years. The effect of this delay can be seen though the low current production (Table I); the national technology used in the production of pellets (Table 2), which are adapted from animal feed production; and low use of this biofuel in the domestic market, resulting in idleness in the industry.

There were only two companies manufacturing pellets in Brazil in 2004; and sixteen currently. The growing demand for alternative resource of renewable energy, to replace oil and its products, explains the expansion of the global pellet market (NUNES et al., 20I6).

TABLE I Pellet production of major producing countries in 2014.

\begin{tabular}{cc}
\hline Country & Pellet production (ktonnes) \\
\hline United States & 6,900 \\
Germany & 2,078 \\
Canada & 1,900 \\
Sweden & 1,577 \\
Latvia & 1,280 \\
France & 1,200 \\
Brazil & 62 \\
\hline
\end{tabular}

Source: Forti; Hemrard (2014)

It is estimated that production de pellets grew $4.0 \%$ per year in Brazil, from 2004 to 2014 , and could be higher, given the amount of agroforestry wastes that do not have any commercial application yet, which could be transformed into agropellets (DIAS et al., 20I2).

According to the pellet producers researched in this study, all nineteen companies that have produced or still produce in Brazil, use waste from the timber industry (Pinus sawdust) as their principal raw material.

Although they are losing ground as raw material in this industry, sugarcane bagasse and Eucalyptus waste were also cited. The first one for having more profitable applications, such as its use in the production of second-generation ethanol, bovine protein nutrition, or even as raw bagasse (with high moisture content $>40 \%$ ) to generate thermal energy for the plant itself; and the second, due to their greater specific gravity and hardness when compared to Pinus, make the compression process more expensive and slower, according to the producers. They also claim that the use of hardwood shortens the lifespan of equipment due to excessive wear caused by mechanical friction. The use of more robust pelletizing equipment, with a preconditioning phase with superheated steam, has been used to process Eucalyptus with materials. Mixing (70\% Pinus and $30 \%$ Eucalyptus) is another practical solution that minimizes the wear and extends the life of the pelletization matrix. 
TABLE 2 Summary of questionnaires sent to agroforestry biomass pellet industries in Brazil.

\begin{tabular}{|c|c|c|c|c|c|c|}
\hline Industry Number & City / State & $\begin{array}{c}\text { Production capacity' } \\
\left(\text { ktonnes } \cdot y^{-1}\right)\end{array}$ & $\begin{array}{c}\text { Used agroforestry } \\
\text { Biomass }\end{array}$ & $\begin{array}{l}\text { Equipment } \\
\text { technology }\end{array}$ & $\begin{array}{c}\text { Operation starting } \\
\text { year }\end{array}$ & $\begin{array}{l}\text { Industry current } \\
\text { situation }\end{array}$ \\
\hline I & Quedas Iguaçú/PR & 6.00 & Pinus & National & 2014 & Producing \\
\hline 2 & Lins/SP & 24.00 & Pinus & National & 2010 & Producing \\
\hline 3 & Telêmaco Borba/PR & 9.00 & Pinus & National & 2004 & Producing \\
\hline 4 & Vale Real/RS & 6.00 & Pinus & National & 2014 & Producing \\
\hline 5 & Benedito Novo/SC & 4.50 & Pinus & National & 2007 & Producing \\
\hline 6 & São JB Vista/SP & 2.40 & Pinus & National & 2014 & Producing \\
\hline 7 & Concórdia/SC & 12.00 & Pinus & Imported & 2014 & Producing \\
\hline 8 & Rio Negrinho/SC & 24.00 & Pinus & Imported & 2008 & Producing \\
\hline 9 & Porto Feliz/SP & 6.00 & Pinus & National & 2004 & Producing \\
\hline 10 & Farroupilha/RS & 3.75 & Pinus & Imported & 2010 & Producing \\
\hline 11 & Itapeva/SP & 3.00 & Pinus & Imported & 2012 & Producing \\
\hline 12 & Piên/PR & 42.00 & Pinus & Imported & 2012 & Producing \\
\hline 13 & Telêmaco Borba/PR & 7.50 & Pinus/Eucalyptus & National & 2014 & Producing \\
\hline 14 & Sengés/PR & 12.00 & Pinus & Imported & 2008 & Ready to produce \\
\hline 15 & Itaju/SP & 7.50 & Pinus & National & 2008 & Ready to produce \\
\hline 16 & Jaú/SP & 24.00 & Sugarcane bagasse & Imported & 2015 & Ready to produce \\
\hline 17 & Maringá/PR & 0.00 & Pinus & National & 2008 & Disabled \\
\hline 18 & Bandeirantes/PR & 0.00 & Pinus & National & 2010 & Disabled \\
\hline 19 & Tunas/PR & 0.00 & Pinus & Imported & 2009 & Disabled \\
\hline 20 & Recife/PE & - & Elephant grass & Imported & 2016 & Under construction \\
\hline 21 & São J. Ausentes/RS & - & Pinus & Imported & 2016 & Under construction \\
\hline 22 & Rio dos Cedros/SC & - & Pinus & National & 2016 & Under construction \\
\hline 23 & Rio Grande/RS & - & Black wattle & Imported & 2016 & Under construction \\
\hline
\end{tabular}

' Working eight-hour shifts per day.

One company said it intends to use sugarcane bagasse, but at the moment, it is not producing since they are expecting better prices and contract proposals for the sale of agropellets, despite all facilities being ready for production. From the four industries that currently have projects under construction, two said they intended to use Pinus, one informed the use of elephant grass and another, black wattle. The choice of raw material is related to the geographic distribution of companies and the availability of residual biomass near the industrial plant. Pinus, as raw material is used by $84.5 \%$ of Brazilian producers, and it is a byproduct of the wood industries of the region where the plant is located, especially south and southeast regions of Brazil. The map of pellet producers shows that there is no pellet industry in other areas of the country; i.e., agroforestry waste available in the North, Northeast and Center-West regions, are not compressed in the form of pellets.

According to Figure I, the distribution of pellets production by region is uneven. Currently, most of the production of Brazilian pellet industries (approximately $81.4 \%$ ) are concentrated in the South, distributed by the states of Parana (PR), Santa Catarina (SC) and Rio Grande do Sul (RS). About $18.6 \%$ of Brazilian pellets are produced in the state of São Paulo (SP), Southeast region of Brazil.

The Map of Pellets 2014 shows the distribution of plants in Brazil (Figure 2). The South and Southeast regions concentrate $73 \%$ of waste from wood industries processed in Brazil (SCHNEIDER et al., 20I2) and is where there are the highest percentages of areas with plantations of Pinus in the country, 84.6\% (IBÁ, 20I5). Therefore, in these regions are grouped all active producers pellets from agroflorestry in Brazil.

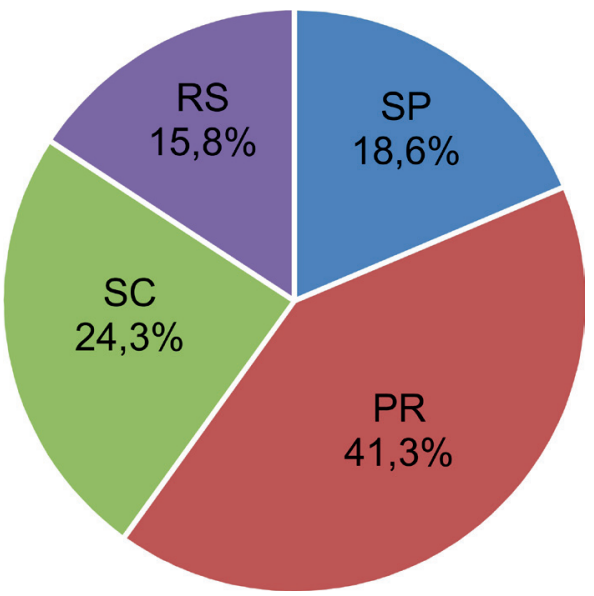

FIGURE I Regional distribution of pellet production in Brazil in 2014.

As for the pelletizing technology used by Brazilian industry, it can be inferred that $57.9 \%$ use national equipments, which has less technological appeal and consequently low productivity, as shown in Figure 3. Similarly, Table 3 data show that the equipment used by pellet producers are small and the Brazilian industry has low capacity. 


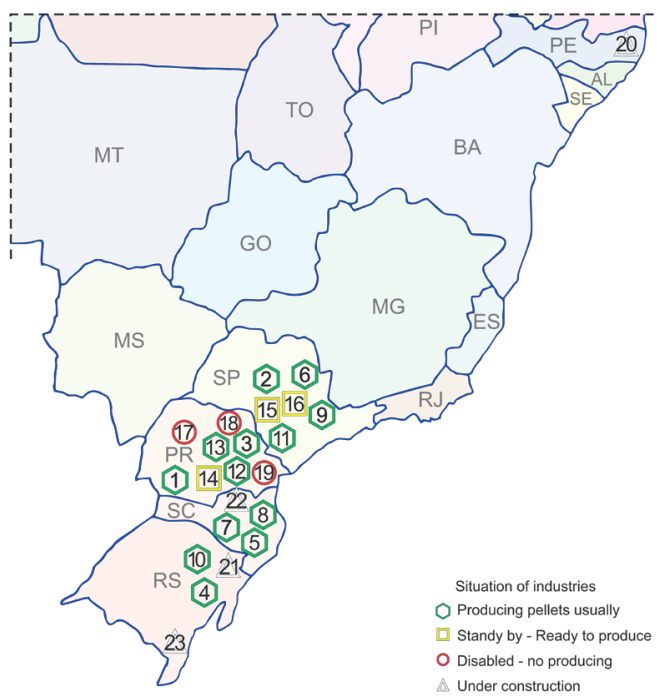

FIGURE 2 Status of pellet producing industries in Brazil in 2014.

In addition, the pellet producers report that domestic manufacturers of pelletizing equipment are in a technology transition phase, from the animal feed pelleting to biomass pelleting, adapting to the physical and chemical characteristics of the agroforestry biomass. Besides the technological issue, the high logistic costs of raw material transport to the factory, and from the pellets to the consumer or to harbors, mentioned by Garcia et al. (2016); Tavares; Tavares (20I5) added the cost of electricity in Brazil, according to Trømborg et al. (2013) is up to four times higher than in the US (\$48.00/MWh), are other factors that contribute to low competitiveness and high idleness of the Brazilian pellet industry.

The pellet-producing companies in Brazil, considering an 8.0-hour shift per day, have a production capacity of about 193.65 ktonnes. $y^{-1}$, but their current production reaches only $25.5 \%$ of this capacity. This research, carried out with producers, found that the production of this renewable fuel was 49.39 ktonnes in Brazil in 2014. This production is larger than the one estimated by IBÁ (20I5) and Lamers et al. (20I2); and lower than the one described by Forti; Hemrard (20l4). The percentage of capacity utilization has declined over the past four years (Figure 3 ) and the producers urge that this high idleness is explained by the lack of domestic demand, due to the lack of knowledge of benefits and advantages in the use of pellets and also because the market is still in a developing phase.

Most Brazilian pellets plants (79 \%) had small pelletizing production between 0.5 to 4.0 tonnes per hour. These technological issues limit the use of pellets within domestic market, which is undeveloped in the country. Besides that, many countries as Sweden, Austria, Germany, USA and Canada, have developed strict quality, storage, transport and agroforestry pellets combustion standards. These takes into account the entire chain of custody, ensuring traceability from raw material production to the final consumer. Most of the domestic equipment do not achieve the quality specifications from ISO I7225-2 and 6 (ISO, 20I4). That is the reason they fail to get the seal of quality, demanded by the companies for exports, restricting the entry of agropellets into the European market. Thus, few surveyed companies are operating with this consumer market (DIAS et al., 20I2).

The sale prices of these biofuels range from $R \$$ 480,00 to $\mathrm{R} \$ 600,00$ per tonnes (Free on Board/Port in Brazil), within Brazilian market. Both in briquettes and pellets production, the high cost and the scale of production are seen as challenges to be overcome (DIAS et al., 20I2; GARCIA, 20I4). Higher production, with better quality and lower cost is the key for these producers to achieve the most profitable export market.

The stagnation of pellet production in Brazil in recent years can be explained by three main factors: (a) lack of knowledge of the advantages of pellets as more efficient energy solution; (b) the pellet business in Brazil is recent and the domestic market is still in a developing stage; (c) Brazilian pellet producers are adapting to European standards for the required certification for export. Currently, the main application has been directed towards the thermal power generation to pizza place, bakeries, hotels, water parks, swimming gyms, paint ovens, food industries, electroplating, industrial laundries, tires retreading and plastic industries. According to the researched producers, these segments consume about 95\% of domestic production. Exotic applications are also found in the Brazilian market, such as pellets to replace the traditional "cat litter", using the remainder (5\%) of the national production of this biofuel.

TABLE 3 Production capacity of the major pellet producers compared to Brazil.

\begin{tabular}{ccccc}
\hline Country & $\begin{array}{c}\text { Number } \\
\text { of pellets } \\
\text { plants }\end{array}$ & $\begin{array}{c}\text { Total } \\
\text { Capacity } \\
\text { (ktonnes/y) }\end{array}$ & $\begin{array}{c}\text { Average } \\
\text { Production of } \\
\text { an industry }\end{array}$ & Reference \\
(ktonnes/y) & \\
\hline United States & 184 & $18,613.45$ & 101.16 & Portz (2016) \\
Canada & 56 & $6,134.00$ & 109.54 & Portz (2016) \\
Brazil & 16 & 193.65 & 12.10 & This paper \\
\hline
\end{tabular}




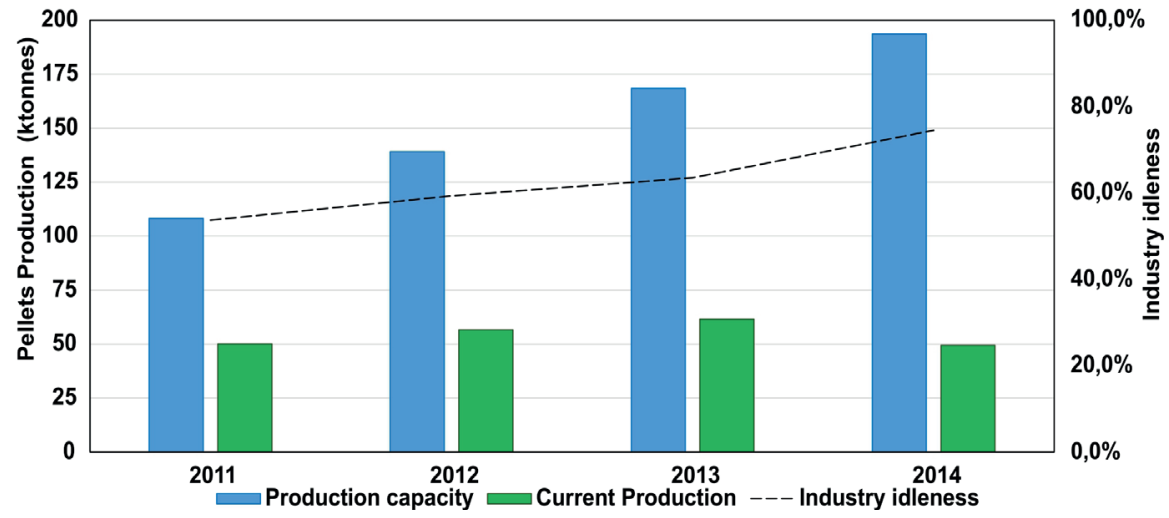

FIGURE 3 Agroforestry biomass pellet production in Brazil vs. industry idleness.

The prospects for consolidating and expanding the pellets industry in Brazil include issues such as support to increase demand, strengthen producers' association, establish quality standards, facilitate the entry of imported equipment with higher production efficiency and technology, and mainly, specific government funding for agroforestry biomass sector, similar to other energy sources. Table 4 shows a systematization of the strategic elements for the consolidation and growth of the pellets industry. This scenario was created from the consultation carried out with producing pellets companies and from analyzes of national and international trends from the literature (DIAS et al., 20 I2; FELFLI et al., 20I I; LAMERS et al., 2012). Based on these analyzes, it is possible to identify the most important elements: establishing priorities for action, directing efforts to overcome technical challenges, providing growth opportunities for the pellets market in Brazil.

Some opportunities need to be better used, so that pellets can occupy a more significant share of thermal power generation in the National Energy Matrix. The approval of Law 12,305/I0, establishing the National Policy on Solid Waste (BRASIL, 20I0), constitutes an instrument for the reduction of waste by encouraging the development of environmental management and business systems aimed at improving production processes and energy reuse of solid waste. Thereby, we expect greater interest in the reuse of waste of agroforestry biomass, favoring its transformation into solid compressed biofuels as pellets and briquettes. In the same sense, the global climate change agreement signed by 195 countries at the Paris Climate Change Conference (COP2I) signaled that there will be a transition to low-carbon energy in the $\mathrm{XXI}$ century and the use of agroforestry biomasses meet the new challenges of cleaner, renewable and sustainable energy
(JOHANNSDOTTIR; MCINERNEY, 2016). However, standards, laws and incentive policies for producers and consumers of biofuels are necessary, as seen in the USA and Sweden. These countries offer subsidies and tax exemptions for the purchase of equipment that uses wood pellets instead of oil or gas. Ease of transport, handling of pellets, lending system for pellets burners used by companies engaged in the food business, such as pizzerias and bakeries, are examples of positive aspects to be strengthened. In large cities, such as São Paulo, where delivery trucks have controlled access only for a few hours early in the morning, the practicality of pelletfuelled furnaces has provided good business to replace those using firewood or gas. The high Brazilian logistics costs, which affect the competitiveness of industries, is an example of negative aspects to be overcome.

Companies know that in the short term there is no solution to these problems. For this reason, they develop industrial plants close to ports and to the raw material, to minimize these costs with transportation. As for the high price of electricity, those companies developing plant designs for compact pellets; aim to minimize energy expenses from unnecessary internal movements. There are many challenges that need to be minimized, such as the absence of regulatory standards of the quality of pellets, which could be solved in Brazil with the acceptance of quality standards in Europe with ISO I7225-2 and 6 (ISO 20I4).

Alternatively, as it happened with charcoal in the state of São Paulo (SAO PAULO, 2003), the government could define through a Resolution, the minimum quality standards required for agroforestry pellets for use in the domestic market. These measures are not definitive solutions to the lack of quality standards, but are emergency proposals in this direction. 
TABLE 4 Strategic action proposals aimed at developing the agropellets market in Brazil. Systematization of the strategic points needing actions to develop the market Inefficient equipment and high maintenance costs;

High freight costs of raw materials and manufactured goods; High energy consumption in the drying process;

Negative aspects to be overcome Competition from oil derivatives, firewood and gas; Vulnerability of the raw materials to moisture content; High cost of electricity in Brazil;

High logistics costs involved in transport (raw material and pellets).

\begin{tabular}{|c|c|}
\hline $\begin{array}{c}\text { Positive } \\
\text { aspects to be } \\
\text { strengthened }\end{array}$ & $\begin{array}{l}\text { Usable Heating Value (UHV) of agropellets; } \\
\text { Products are compact, homogeneous and clean; } \\
\text { Ease of transportation, handling and storage; } \\
\text { Low emissions of gases and particulates; } \\
\text { Reduce dependence on fossil fuels and their derivatives; } \\
\text { Less environmental impact, as it is renewable and sustainable energy. }\end{array}$ \\
\hline $\begin{array}{c}\text { Challenges to be } \\
\text { minimized }\end{array}$ & $\begin{array}{l}\text { Few domestic laboratories to perform complete analysis of the quality of pellets as required by ISO } 17225 \text { (ISO 2014); } \\
\qquad \begin{array}{c}\text { Seasonality of agricultural production and waste generation; } \\
\text { Low annual production capacity; } \\
\text { Lack of government subsidies for the agroforestry biomass sector; } \\
\text { Absence of rules governing the quality, production and use of pellets. }\end{array}\end{array}$ \\
\hline $\begin{array}{l}\text { Opportunities to } \\
\text { be seized }\end{array}$ & $\begin{array}{l}\text { Implementation of the National Solid Waste Policy; } \\
\text { Multiple applications of pellets (boilers, pizzerias, industries, hotels, parks); } \\
\text { Product diversification (thermal energy, pet market as cat litter, sanitary napkins); } \\
\text { Replace wood from native forests for more practical and efficient reforestation products; } \\
\text { More competitive when Dollar (USD\$) is more profitable than Real (R\$); } \\
\text { Adding value to agroforestry waste and improving efficiency of the supply chain. }\end{array}$ \\
\hline
\end{tabular}

\section{CONCLUSIONS}

This study concludes that the Brazilian pellet industry is young but has great potential for expansion. In addition, it may contribute to the strengthening of the Brazilian sustainable energy matrix. Brazil needs to develop the internal market of pellets to reduce industry idleness; In Brazil there are sixteen companies producing pellets. Three organizations are ready to produce and four industrial projects are under construction; Brazil currently produces 49.39 ktonnes. $y^{-1}$ of pellets, despite the fact of having the capacity to produce up to four times this amount; Pinus waste is the main raw material used for the production of pellets, with a $95 \%$ stake; $57.9 \%$ of pelletizing equipment used by pelletizing companies are national; $100 \%$ of the pellet producing companies are located in the South and Southeast of Brazil, where there is greater concentration of forest-based industries and increased availability of agroforestry waste.

\section{REFERENCES}

ARRANZ, J. I.; MIRANDA, M.T.; MONTERO, I.; SEPÚLVEDA, F.J.; ROJAS, C.V. Characterization and combustion behaviour of commercial and experimental wood pellets in South West Europe. Fuel, v. I42, p. 199-207, 2015.

BASU, P.; BUTLER, J.; LEON, M. A. Biomass co-firing options on the emission reduction and electricity generation costs in coal-fired power plants. Renewable Energy, v. 36, n. I, p. 282-288, 2011 .
BRASIL. Ministério do Meio Ambiente, Lei I 2.505/ 10 - Política Nacional de Direcionamento Resíduos Sólidos (PNRS). $2^{\mathrm{a}}$. ed. Brasília, 2010. 72 p.

DIAS, J. M. C. S.; SOUZA, D.T.; BRAGA, M.; ONOYAMA, M. M.; MIRANDA, C.H.B.; BARBOSA, P. F. D.; ROCHA, J. D. Produção de briquetes e péletes a partir de resíduos agrícolas, agroindustrais e florestais. Ia ${ }^{a}$ ed. Brasília: Embrapa Agroenergia, 2012. 132 p.

FELFLI, F. F.; MESA, J.M.P.; ROCHA, J.D.; FILIPPETTO, D.; LUENGO, C. A.; PIPPO, W. A. Biomass briquetting and its perspectives in Brazil. Biomass and Bioenergy, v. 35, n. I, p. 236-242, 20 II.

FORTI, R.; HEMRARD, M. Agriculture, forestry and fishery statistics: Roundwood, fuelwood and other basic products. Luxembourg: EUROESTAT, 2014.

GARCIA, D. P. Pellets de Madeira: Uma questão de competitividade e preço. Revista da Madeira, v. 138, n. 6, p. 35-38, 2014.

GARCIA, D. P.; CARASCHI, J. C.; VENTORIM, G. Caracterização energética de pellets de madeira. Revista da Madeira, v. 135, n. 2, p. 14-18, 2013.

GARCIA, D. P.; CARASCHI, J. C.; VENTORIM, G. Decomposição térmica de pellets de madeira por TGA. Holos, v. I, n. 32, p. 327-339, 2016.

IBÁ. Indústria Brasileira de Árvores: Indicadores de desempenho do setor nacional de árvores plantadas referentes ao ano de 20I4. São Paulo, 20I5. 100 p. 
INTERNATIONALORGANIZATIONFORSTANDARDIZATION.

ISO I7225-2: 2014 - Solid biofuels - Fuels especication and classes - Part 2 - Graded pellets. Brussels, 2014.

INTERNATIONALORGANIZATIONFORSTANDARDIZATION.

ISO I7225-6: 2014 - Solid biofuels - Fuels especication and classes - Part 6 - Graded non wood. Brussels, 2014.

JOHANNSDOTTIR, L.; MCINERNEY, C. Calls for Carbon Markets at COP2I: a conference report. Journal of Cleaner Production, v. I24, n. June, p. 405-407, 2016.

JOHNSTON, C. M. T.; VAN KOOTEN, G. C. Back to the past: Burning wood to save the globe. Ecological Economics, v. I20, n. October, p. 185-193, 2015.

LAMERS, P.; JUNGINGERB, M.; HAMELINCKC, C.; FAAIJ, A. Developments in international solid biofuel trade An analysis of volumes, policies, and market factors. Renewable and Sustainable Energy Reviews, v. 16, n. 5, p. 3176-3199, 2012.

NUNES, L. J. R.; MATIAS, J. C. O.; CATALÃO, J. P. S. Wood pellets as a sustainable energy alternative in Portugal. Renewable Energy, v. 85, p. I0II-1016, 2016.

OBERNBERGER, I.; THEK, G. Physical characterisation and chemical composition of densified biomass fuels with regard to their combustion behaviour. Biomass and Bioenergy, v. 27, n. 6 , p. $653-669,2004$.

PORTZ, T. Plants and Pellet Producers List. Biomass Magazine: $\mathrm{BBI}$ Internacional. Available at: <http:// biomassmagazine.com/plants/listplants/pellet/US/ $>$. Accessed in: 16 may 2016.
PROSKURINA, S.; RIMPPI, H.; HEINIMÖ, J.; HANSSON, J.; ORLOV, A.; RAGHU, K.C.; VAKKILAINEN, E. Logistical, economic, environmental and regulatory conditions for future wood pellet transportation by sea to Europe: The case of Northwest Russian seaports. Renewable and Sustainable Energy Reviews, v. 56, p. 38-50, 2016.

RAMOS E PAULA, L. E.; TRUGILHO, P. F; NAPOLI, A.; BIANCHI, M. L. Characterization of residues from plant biomass for use in energy generation. Cerne, v. 17, n. 2, p. 237-246, 201 I.

SÃO PAULO (Estado). Secretaria de Agricultura e Abastecimento de São Paulo (SAA). Resolução $\mathbf{n}^{\circ} \mathbf{1 0}$, de I I de julho de 2003. São Paulo: 2003.

SCHNEIDER, V. E.; PERESIN, D.; TRENTIN, A. C.; BORTOLIN, T. A.; SAMBUICHI, R.H.R. Diagnóstico dos Resíduos Orgânicos do Setor Agrossilvopastoril e Agroindústrias Associadas - IPEA. Instituto de Pesquisa Econômica Aplicada, 20I2. I34 p.

TAVARES, M. A. M. E.; TAVARES, S. R. L. Perspectivas para a participação do Brasil no mercado Internacional de pellets. Holos, v. 5, n. 3I, p. 292-306, 2015.

TRØMBORG, E.; RANTA, T.; SCHWEINLE, J.; SOLBERG, B.; SKJEVRAK, G.; TIFFANY, D.G. Economic sustainability for wood pellets production - A comparative study between Finland, Germany, Norway, Sweden and the US. Biomass and Bioenergy, v. 57, p. 68-77, 2013.

WALTER, A.; DOLZAN, P. Sustainable Bioenergy Trade: Securing Supply and Demand. Country Report Brazil IEA, Task 40. UNICAMP: Campinas, 20I4. 65 p.

YAMAII, F.M.; VENDRASCO, L.; CHRISOSTOMO, W.; FLORES, W.P. Análise do Comportamento de briquetes. Energia na Agricultura, v. 28, p. II-I5, 2013. 